\title{
Governing Difference in India and China: an introduction
}

Kaur, Ravinder; Wahlberg, Ayo

Published in:

Third World Quarterly

Publication date:

2012

Document version

Early version, also known as pre-print

Citation for published version (APA):

Kaur, R., \& Wahlberg, A. (2012). Governing Difference in India and China: an introduction. Third World Quarterly, 33(4), 573-580. http://www.tandfonline.com/doi/pdf/10.1080/01436597.2012.657418 
This paper has been accepted for publication in Third World Quarterly, and the final (edited, revised and typeset) version of this paper will be published in Third World Quarterly, Volume 33, by Taylor \& Francis, All rights reserved. C Taylor \& Francis

Special issue of Third World Quarterly

\title{
Governing Difference in India and China An Introduction
}

\author{
Ravinder Kaur \& Ayo Wahlberg
}

Inequality and social difference are the primary themes that have come to define the current financial turmoil and political unrest in various parts of the world - from the market square in Sidi Bouzid, Tunisia to Zucotti Park in New York. As the financial crisis increasingly threatens the familiar global economic structures, the inequality such structures engendered have been revealed in plain sight for everyone to see. Thus, it is hardly a coincidence that the resistance against a variety of inequalities and inequities appears precisely when the financial world is in a state of crisis of its own. These developments offer a fresh vantage point from where to rethink the questions of difference in the form of inequality and inequity together with that of national identity making in a globalised world. In this special issue, we approach these questions from two locations - India and China - that might be considered unusual given that both these nations have not only maintained high economic growth rates, and therefore are said to have circumvented the gloom of financial crisis, but are also seen as the 'rising' global powers that are expected to reshape the global institutional framework. Perhaps this is precisely what makes it interesting to rethink inequality, inequity and identity from these locations said to be very different in their political frames of democracy and authoritarianism - to witness not only the concrete transformations taking place in these societies, but also how the very languages and hegemonic discourses that have long described the world for us are in a state of transformation. As we argue in this issue, not only are the patterns of global inequality between states and world regions in a state of flux, they are also being reproduced, sometimes violently so, within national boundaries of socially uneven neoliberal societies such as India and China as the various contributions to the special issue show. The contributions collectively also show how the popular conceptions of India and China based on their political framing - democratic and authoritarian respectively - do not help us understand the transformations taking place in these societies. As the case studies show, the Indian state is as capable of authoritarian actions against its own population while Chinese state often engages in extensive negotiations at local levels. Clearly the simple classifications in currency do not allow us a clear understanding of the ongoing transitions that have positioned these nations as leading global players.

As we enter the second decade of the $21^{\text {st }}$ century, the question of discourse - how to describe the contemporary world beyond the language of north /south, developing/developed and first/third has understandably once again gained a particular urgency especially within a narrative context of "Asia Rising", this time with all focus firmly fixed on China and India. ${ }^{1}$ The boundaries etched in the $20^{\text {th }} \mathrm{C}$ seem unsettled and in fact plain ineffective in helping us understand the current geographies of difference. This is especially so as we confront the popular discourse of 'emerging 
This paper has been accepted for publication in Third World Quarterly, and the final (edited, revised and typeset) version of this paper will be published in Third World Quarterly, Volume 33, by Taylor \& Francis, All rights reserved. (C) Taylor \& Francis

powers' that seems to have destabilised the categories we have long been familiar with. The relentless 'rise' of India and China is now the subject of both hyperbolic and apprehensive speculations in international media reporting as well as academic deliberation spanning the fields of political science, economics, sociology, anthropology and humanities. This euphoric discourse is complicated by the fact that the impressive economic growth in these nations has not yet translated into lifting populations out of poverty or geo-political rebalancing. The Indian and Chinese states struggle to govern tumultuous differences within - inequities and inequalities constitutive of the socio-economic and political terrain; rich/poor; urban/rural; cosmopolitan/vernacular; ethnic majorities/minorities - accentuated by neoliberal market reforms, even as they seek to project a unified 'national difference' that can compete profitably with other nations on a global scale. Tensions are playing out between 'cosmopolitan' convergence and 'multicultural' diversity, between expanding middle classes and increasingly disenfranchised poor groups, between the global and the local. Difference, here, at once, appears as a desirable condition in relation to the concept of 'global nation' as well as a challenge that threatens to unravel the very weave of the nation.

In this special issue of Third World Quarterly, we address the problem of governing difference, or better yet of governing multiple forms of difference - objects of desire as well as fear - that are simultaneously courted and denounced. This multipronged approach to difference becomes particularly palpable in 'emerging' powers like India and China witnessed in a snapshot of transformation - unsettled within and unsettling the current global order. While these nations actively seek to construct a distinctive global identity - nation branding - in order to demarcate themselves from other nations, they also seek to subordinate and eradicate difference within the nation. Difference in need of subordination is that which is seen as disharmonious, contrary and even threatening to the nation's externally projected image as a unified, prosperous and influential power. This unruly 'internal other' is witnessed under flexible and interchangeable signs: the poor, the rural migrants, the militants, the separatists, the dissidents and the religious minorities to name a few. When difference is permitted - sometimes even flaunted - under the signs of diversity and multiculturalism, it only comes into being within a prior consensual framework. The ungovernable difference, or the non-consensual, is what becomes subject to violence and coercion in one form or the other. It is in this broad sweep that we explore the taxonomies of difference and conflicts to govern those in contemporary India and China.

The notion of difference, of course, has a rich theoretical history. Since the closing decades of the $20^{\text {th }}$ century, it has in particular been fleshed out in the fields of multicultural, postcolonial, sexuality and disability studies. ${ }^{2}$ One element that these strands have had in common is a theorising of difference as something that is staged, performed, maintained, fixed and/or contested as a matter of identity politics in contexts of domination/subjugation and power/knowledge. As argued by Stuart Hall: “'difference' is ambivalent. It can be both positive and negative. It is both necessary for the production of meaning, the formation of language and culture, for social identities and a subjective sense of the self as a sexed subject - and at the same time, it is threatening, a site of 
This paper has been accepted for publication in Third World Quarterly, and the final (edited, revised and typeset) version of this paper will be published in Third World Quarterly, Volume 33, by Taylor \& Francis, All rights reserved. (C) Taylor \& Francis

danger, of negative feelings, of splitting, hostility and aggression towards the 'Other"'.3 A second element that these strands of study have shared has been in glimpsing a kind of emancipatory potential within 'difference' as it hints at possible routes out of racist, chauvinist, and Eurocentric hierarchies- one must "pay attention to difference without creating a hierarchy of difference". 4 Difference here emerges as a kind of platform for mobilisation, as suggested by Arturo Escobar whose Afro-Colombian informants "engage in the defence of place from the perspective of the economic, ecological, and cultural difference that their landscapes, cultures, and economies embody in relation to those of more dominant sectors of society". 5

While sharing these scholars' preoccupation with matters of identity and inequality, we nevertheless propose to shift attention towards mundane questions of how difference is constructed, manifested, governed, mobilised and obscured. We are interested not so much in claims to difference as in the making of difference in socially uneven societies, particularly those fuelled by neoliberal economic growth, such as China and India. ${ }^{6}$ In such contexts, as we have argued, dichotomies of developed/underdeveloped, North/South or emerging/backward as unifying national or regional categories are rendered entirely obsolete. At best they might be folded back into the nations as classificatory schemes to parcel out various demographic or political groups within the nations. What we argue in this collective intervention, however, is that such an analytic move will inevitably fall short. Instead we are compelled to seek another conceptual language, outside these binaries, that enables us to explore, describe and make sense of the ongoing transformations in these societies. We suggest a turn to the languages of difference as a frame within which to explore contemporary India and China as a contribution to ongoing conceptual development and innovation around which to rethink social unevenness and the making of global identities.

Central to this conceptual shift is the idea of difference that underpins projects of identification, classification and naming of objects, peoples, places and ideas. Difference is often seen as a readily discernible relation between two entities each with a prior identity. While such a relation is largely built upon contradiction and mutual negation of the two, Gilles Deleuze has argued for a positive approach towards difference. ${ }^{7}$ This means moving beyond identity of a given entity to look for the underlying processes that constitute the reasoning behind empirical distinctions. Instead of locating difference within a frame of dichotomies, we view it synoptically in its interwoven layers of multiplicity - linking seemingly disparate terrain, and revealing interconnections that make the inside and the outside of a nation. We approach difference as constitutive of a range of languages of difference revealing specific configurations and patterns that come together in various ways in disparate contexts. It is the effects of difference, rather than attempts to ascertain what differences there in fact are in India and China, that articles in this issue analyse.

Without claiming to be definitive, we isolate three languages of difference as especially relevant for understanding the problems posed in this special issue. These are difference spoken of as standardisation, commodification and alterity produced upon a matrix of social unevenness and 
This paper has been accepted for publication in Third World Quarterly, and the final (edited, revised and typeset) version of this paper will be published in Third World Quarterly, Volume 33, by Taylor \& Francis, All rights reserved. (C) Taylor \& Francis

identity making. Each of these languages are seen in spectacular as well as ordinary, mundane processes that constitute everyday life. While none of these presuppose each other, they remain entangled even in their seemingly distinctive spaces where imperatives of governance, authority of state power and individual freedoms and desires compete, collide and cohere. These languages are not deployed by state powers alone to exercise authority and enhance legitimacy; state-like authorities as well as those in opposition also make use of difference as a ground for action.

First, the modernist discourse and practices of standardization through which nations are arranged, classified and displayed in a global hierarchy - patches of difference woven in a universal frame. Since the past few decades, the nations have routinely been subjected to measurement and comparison with other nations on universal parameters. These parameters range from as diverse themes as poverty, human development, economic growth rate and per capita consumption to that of free speech, transparency, corruption, and good governance and even that of beauty. ${ }^{8}$ The result is an array of standardised nation indexes through which distant societies become instantly familiar, knowable and comparable. This classification is predicated upon differences made palpable that distinguish one nation from the other within a comprehensible scheme - for instance, Indianness and Chineseness become legible only within such a universal frame. And at the same time, it privileges one attribute - of comparison - over several others, thereby creating an internal play of elements that reveal a specific and limited gaze through which to know the nation. Shades of Derrida's notion of differánce here: reading difference together with its other meaning of deferment or absence allows one to witness the play of difference where one pattern of difference becomes prominent only to defer other patterns into the background. ${ }^{9}$ The practice of standardising and indexing nations on various scales - upon which nations can aspire to 'rise' or risk a 'fall' if found lacking - now constitutes a global regime of knowledge that both informs and reconfigures the place of a nation within the world. To govern difference, therefore, is precisely to make it palpable, comparable and thereby calculable. Second, the related processes of commodification of thus created inalienable, essential cultural difference - identity - of nations, communities and regions that make tangible and intangible national or ethnic goods saleable in the global markets. In fact, the very idea of a viable nation has become interlinked with the ability of the nation to enhance and realise its exchange value in the global circulation of capital.

Third, the emotive claims and assertions of alterity deployed not only to identify the dangerous 'other', but also to justify one's disengagement - self alienation - from the society at large. The making of the other has long been noted as an imperial technology that enables the dominant power to define itself through marginalisation and exclusion of the other. ${ }^{10}$ Difference is implicated in the processes of othering where fear and violence reinforce each other, and yet where the question of outrage largely remains in ambivalence. The power to outrage and be outraged allows one to arbitrate simultaneously on what is in excess and therefore in need of condemnation, and what actions are necessary to contain the outrage and therefore praiseworthy. This privilege of arbitration is central to the drawing and redrawing of internal boundaries, and re/imagining the dangers that can be countered in new battlegrounds. The assertion of alterity can be witnessed in the double 
This paper has been accepted for publication in Third World Quarterly, and the final (edited, revised and typeset) version of this paper will be published in Third World Quarterly, Volume 33, by Taylor \& Francis, All rights reserved. ( Taylor \& Francis

edged exclusionary mechanisms - both in the processes of marginalisation where the other is pushed to the limit, and the processes of abandonment where the privileged retreat to their securitised exclusive zones beyond the reach of the other. The quest for alterity is similarly implicated in the processes of individual self-making in relation to - or sometimes in stark opposition to - the rapid transformations that seem to overtake the current way of life.

The articles that follow approach these issues at national, provincial and indeed individual levels, showing how national projects to firmly place India and China on to a global scene come into tension with the social unevenness found within their borders. David Ludden sets the stage, in his analysis of imperial modernity in Asia: "Modern capitalist imperialism crowned Europeans with supreme status, and Asian nationalists fought European imperialists to make free nations, but a reproduction of old imperial forms of inequity also occurred inside transitions from empire to nation in Asia, which continues to shape patterns of global inequality today". Structures of inequity, he argues, are part and parcel of Asia's rise as patterns of global inequality - whereby the poorest $20 \%$ of the world's population account for $1.4 \%$ of global wealth and the richest $20 \%$ account for $80 \%$ come to be reproduced in countries like India and China.

Within this context of inequity and social unevenness, a cluster of articles take on the challenge of analysing nation-building - or indeed nation branding - processes in China and India, as these two countries take concrete steps to position themselves globally as modern nations with particular qualities and advantages. Ravinder Kaur's analysis of Brand India, shows us how images are mobilised in advertising campaigns to "mediate the attractiveness of an investor friendly nation in aesthetically pleasing frames" in an emerging field of nation-branding. The paper invokes image as the site where a desirable global identity for the nation is carved out in ways that sometimes bear little resemblance to the social life outside the image frames. Thus, the world of images is also where ruptures in the nation's body take place when the simulated model of the ideal nation is superimposed over the real territory to reveal the violent scars of market transition. Similarly, Ayo Wahlberg provides an analysis of ongoing global negotiations which have placed China on the global biotech map as an 'emerging power'. This negotiation has involved efforts, on the one hand, to specify those qualities and assets that make China attractive as a biotech nation, and on the other, to identify those ethical challenges related to the recruitment of volunteer research subjects that are specific to a 'Chinese context'. Such global negotiations contribute palpably to nation-building processes. And in yet another arena, namely an emerging global Indian art market, Manuela Ciotti argues that in circuits of the global art world, value is created through inscribing 'Indianness' to local objects. What these articles show in their different arenas is how India and China are jostling for place within global circuits of commodity exchange, knowledge production and nationbranding, and in the process articulations of what constitutes 'Indianness' or 'Chineseness' are set in motion. Both in terms of that which sets apart but also the contrasts and paradoxes they embody. At a subnational level, Tommaso Bobbio shows us how similar branding processes are going on within India, as he documents the emergence of a 'Vibrant Gujarat' campaign to lure global 
This paper has been accepted for publication in Third World Quarterly, and the final (edited, revised and typeset) version of this paper will be published in Third World Quarterly, Volume 33, by Taylor \& Francis, All rights reserved. (C) Taylor \& Francis

investors to the regional state. This campaign was the culmination of a wider set of articulations about the 'attractive' (from a business point of view) qualities of Gujaratis as a thrifty people who are "more westernised and modernised than the rest of India". In these cases, difference is mobilised as a value proposition, a way to make a case for the attractiveness of India or China as a destination for investors, corporations, biotech scientists or art dealers.

Yet, such 'success portrayals', of course, stand in glaring contrast to the inequity and unrest which permeate both countries and which are the focus of another cluster of articles in this special issue. For, as we have already noted, while concerted efforts are being directed towards building up and projecting 'unified wholes' in a global world, state authorities and officials are also struggling to contain differences within. Based on field work among local government officials and villages in North and South 24 Parganas, Swagato Sarkar argues that the rise and fall of the Left Front government in West Bengal can be accounted for through its failed effort to guide industrial transition in West Bengal. He suggests that as the government embarked on acquiring land for industrialisation, marginalised groups remained dependent despite the introduction of a series of 'development' and 'self help' interventions. In China, Jesper Zeuthen has carried out fieldwork on the outskirts of Chengdu in Sichuan province, where he interviewed people who had been affected by urban-rural integration schemes. In his article, Zeuthen shows how urban-rural boundaries are rarely fixed as local peasants as well as local government officials frequently 'worked the system', mobilizing categorizations as a way to get access to, for example, better compensation for a demolished house, funds earmarked for integration schemes or access to land. He argues that at the urban fringe in Chengdu, "both rule and claims-making were powered by difference" as manifest in different categorizations. In an analysis of how the armed conflict between Maoist guerrillas and the government of India in Chattisgarh comes to be portrayed by government spokespersons and national media, Nandini Sundar argues that the conflict is as much an emotional war as it is an armed conflict. While outrage is directed at the death of 'worthy victims', the deaths of 'unworthy victims' are barely noticed in the media or in government statements. Emotions, she suggests, "are brought in to justify and structure the course of war" through processes of emotional conscription aimed at 'winning hearts and minds'. In these cases, differences emerge out of interventions into the daily lives of villagers, suburban populations and soldiers. The formation of difference through administrative categorizations, media coverage of armed conflicts or industrialization programmes has palpable effects on people, yet difference is also mobilized by these same people in their efforts to, for example, gain land, generate sympathy or make claims.

In a final cluster of articles, we are given insight into what Peter van der Veer calls 'secularism as a project' as opposed to secularisation as a process. He argues that in both India and China, secularism has been utilised as a strategy of national development: "secularism is not simply antireligious in these societies... it simultaneously attempts to transform religions into moral sources of citizenship and national belonging". Such an approach, he shows, allows us to understand how different forms of secularism take hold in different places, rather than assuming that a uniform process of secularisation will take place the world over. In a secular China, the Communist Party 
This paper has been accepted for publication in Third World Quarterly, and the final (edited, revised and typeset) version of this paper will be published in Third World Quarterly, Volume 33, by Taylor \& Francis, All rights reserved. C Taylor \& Francis

has played an important role in the mobilisation of the masses although, as Susanne Bregnbæk shows us in her article on the quandaries of young students aiming to become party members, the place and regard of the Party has certainly undergone changes. Bregnbæk's very intimate account of the split subjectivities of two university students in Beijing who were aspiring party members, shows us how difference can be negotiated as a matter of self formation. As one of her informants who had come to Beijing from another province reflects: "people from the rural areas... lack confidence because we live in a modern city but we are from less developed areas".

Thus, by shifting our analytical focus to the ways in which difference is made and governed and away from the ways in which difference authorises certain claims or vantage points, we argue in this special issue that a new conceptual language is required if we are to come to grips with ongoing transformations and transitions in countries like India and China, and indeed globally. The empirical studies contained within demonstrate the traction that can be gained from such a shift, but this special issue remains a call to arms. If we indeed are to leave behind the kinds of dichotomies that have hitherto cemented global difference, then we must go to those locations in which difference is made, governed, mobilised and obscured. 
This paper has been accepted for publication in Third World Quarterly, and the final (edited, revised and typeset) version of this paper will be published in Third World Quarterly, Volume 33, by Taylor \& Francis, All rights reserved. C Taylor \& Francis

\footnotetext{
${ }^{1}$ The usefulness of the discourse of 'third world' has already been a subject of intense debate. See for example, "The Third World is disappearing", see Nigel Harris, The end of the Third World. Newly industrializing countries and the decline of an ideology, I.B. Tauris. London, 1986, p 300; “[T]he rise of East Asia, the demise of the 'Second World' and the onset of a new era of global capitalism, throws the problems associated with the continued use of the term 'Third World' into sharp relief", see Berger, Mark, The End of the 'Third World'? Third World Quarterly, Vol. 15, No. 2 (Jun., 1994), p257; "[There is a] need to move beyond the paradigm of modernity within which the Third World has functioned as a key element in the classificatory hierarchy of the modern/colonial world system", Arturo Escobar 'Beyond the Third World: imperial globality, global coloniality and antiglobalisation, social movements', Third World Quarterly, Vol 25, No.1, 2004, pp 224-225; and "the age of the Third World has passed irrevocably into history", Mark T. Berger 'After the Third World? History, destiny and the fate of Third Worldism', Third World Quarterly, Vol 25, No.1, 2004, p30. See especially Third World Quarterly (25:1) special issue "After the Third World?" from 2004 guestedited by Mark Berger.

${ }^{2}$ On the multicultural, postcolonial, sexuality and disability studies respectively, see Stuart Hall 'The Spectacle of the 'Other' in Stuart Hall (Ed.) Representations. Cultural Representations and Signifying Practices. London: Sage and The Open University, 1999, pp. 223-279; Escobar, Arturo, Territories of Difference, Duke: Duke University Press, 2008; Butler, Judith Bodies That Matter: On the Discursive Limits of "Sex", London, Routledge, 1993; Butler, Judith, Gender Trouble: Feminism and the Subversion of Identity, New York, Routledge, 1990; Pothier, Dianne \& Devlin, Richard, Critical Disability Theory: Essays in Philosophy, Politics, Policy, and Law, Vancouver, UBC Press, 2006.

${ }^{3}$ Hall 1999, p238.

${ }^{4}$ Devlin \& Pothier 2006, p12.

${ }^{5}$ Escobar 2008, p6

${ }^{6}$ While we focus on India and China in this special issue of TWQ, one could easily include countries like Brazil, Russia or South Africa, among many others, in the analysis.

${ }^{7}$ Deleuze makes a critique of the Hegelian approach and argues that difference should be an object of affirmation rather than negation. See Gilles Deleuze, Difference and Repetition, London, Continuum, 2009.

${ }^{8}$ Some examples would include Human development Index, Transparency International Index, Freedom Index, and the annual Ms Universe competition.

${ }^{9}$ Derrida, Jacques, Writing and Difference, London, Routledge, 2001.

${ }^{10}$ Bhabha, Homi, 'Of Mimicry and Man: The Ambivalence of Colonial Discourse', October, Volume 28, 1984, pp 125-133.
} 